\title{
Paradigm Uniformity and Contrast in Russian Vowel Reduction
}

\author{
Christina Y. Bethin \\ Stony Brook University
}

Reduction of non-high vowels in unstressed syllables to [e] or [ə] after non-palatalized consonants (akan'e) in Contemporary Standard Russian is complete in all positions in the native lexicon (Avanesov, 1972, and others) and it is analyzed as phonological vowel neutralization (Halle, 1959/1971; Crosswhite, 1999/2001, 2004; Barnes 2006a, b). But reduction of non-high vowels after palatal(ized) consonants (ikan'e) shows some exceptional behavior: There is a systematic sub-phonemic contrast between [I] (approximately F 1=300, F2=2000; Thelin 1971) and [ə] (approx. F1=375, F2=1775; Thelin 1971) in a set of inflectional suffixes where [ə] is found instead of the expected [I], exemplified by the forms in (1) below. This reflects the standard pronunciation of Russian as described in Avanesov (1972:69-72, 152-62), Kuzmina (1968), Timberlake (2004:48-51), and holds for most speakers of CSR.

(1) Incomplete neutralization after palatalized consonants in suffixes (near-merger)

\begin{tabular}{|c|c|}
\hline sea' & $\begin{array}{l}/ \mathrm{mó}^{\mathrm{j}}+\mathrm{o} / \text { nom/acc sg } \\
/ \mathrm{mó}^{\mathrm{j}}+\mathrm{a} / \text { gen sg } \\
/ \mathrm{mó}^{\mathrm{j}}+\mathrm{e} / \text { prep sg }\end{array}$ \\
\hline
\end{tabular}

The incomplete neutralization occurs as incomplete merger for $/ \mathrm{e} /, / \mathrm{o} /$, and $/ \mathrm{a} /$ in that $/ \mathrm{e} /$ is $[\mathrm{I}]$, /a/ is most often [ə], and /o/ may be either [I] or [ə], as in (1) above, and it also occurs as phonemic split in that unstressed /o/ and /a/ may be either [I] or [ə], as shown in (2).

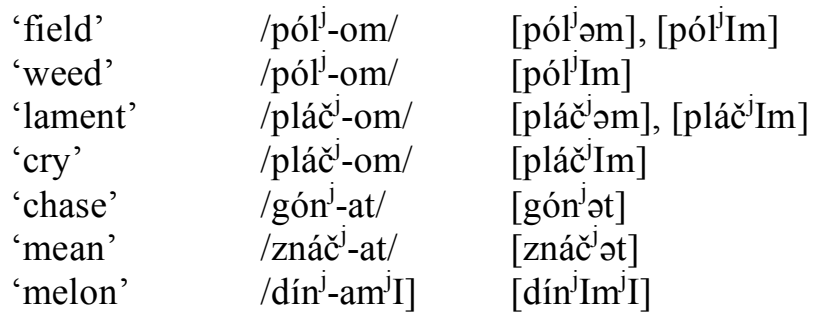
noun, neut instr sg verb, 1 pl nonpast noun, neut instr sg verb, 1 pl nonpast verb, 3 pl nonpast verb, 3 pl nonpast noun, instr $\mathrm{pl}$

Grammatical analogy cannot account for cases where the same model produces different results; phonetic accounts cannot explain why different variants obtain under the same phonetic conditions; and it is not clear why orthography should influence the pronunciation of suffixes and then only certain suffixes and only after palatal(ized) consonants. Language change now favors [I] in certain categories, but in others schwa remains predominant (Avanesov 1972; Kuz'mina 1966; Panov 2004; Timberlake 2004:48-51). So the questions are: 1) where and why is change to [I] particularly favored?; and 2) where and why is schwa particularly entrenched?

I argue that vowel reduction after palatal(ized) consonants is constrained by paradigm uniformity and contrast (Kenstowicz 2005): In certain cases [ə] is entrenched because it maintains critical contrasts within the paradigm (e.g., singular vs. plural in nouns and verbs), while in other categories [I] is especially favored because it enforces paradigm uniformity (adjective suffixes for palatal(ized) stems) or because it supports palatalization as the salient marker of a given morphosyntactic category (verbal non-past suffixes). Most examples of incomplete neutralization in the literature deal with incomplete merger (see Barnes 2006a; Yu 2007), so these exceptions to $i k a n$ 'e are of interest because they also show a type of phonemic split. This preliminary study suggests that sub-phonemic contrasts in Standard Russian may be grammar-internal and maintained by the morphology (Yu 2007). It is not yet entirely clear whether ikan'e is 
phonological neutralization (Jakobson 1929/1971:100; Halle 1959/1971:70-71; Lightner 1968; Trubetzkoy 1934) or a gradient phonetic process (see Thelin 1971; Padgett 2004; Padgett and Tabain 2005; Barnes 2006a, b), but under either view the implementation of paradigm uniformity and contrast in the grammar would give similar results.

References

Avanesov, R. I., 1972. Russkoe literaturnoe proiznoshenie. Prosveshchenie, Moscow. Barnes, J., 2006a. Strength and Weakness at the Interface: Positional Neutralization in Phonetics and Phonology. Mouton de Gruyter, Berlin and New York.

Barnes, J., 2006b ms. Phonetics and phonology in Russian unstressed vowel reduction: A study in hyperarticulation. Boston University ms.

Crosswhite, K., 2001. Vowel Reduction in Optimality Theory. Routledge, New York and London.

Crosswhite. K., 2004. Vowel reduction. In: Hayes, B., Kirchner, R., Steriade, D. (Eds.) Phonetically Based Phonology. Cambridge University Press, Cambridge, pp. 191231.

Halle, M., 1959/1971. The Sound Pattern of Russian. $2^{\text {nd }}$ printing. Mouton, The Hague.

Jakobson, R., 1929/1971. Remarques sur l'évolution phonologique du russe comparée à celle des autres langues slaves. Rpt. in Selected Writings, Vol. 1. Phonological Studies, $2^{\text {nd }}$ exp. ed. Mouton, The Hague and Paris, pp. 7-116.

Kenstowicz, M., 2005. Paradigmatic uniformity and contrast. In: Downing, L., Hall, T. A., Raffelsiefen, R. (Eds.) Paradigms in Phonology. Oxford University Press, Oxford, pp. 145-169.

Kuz'mina, S. M., 1968. Chapter 4. Fonetizatsiia zaudarnogo vokalizma vo fleksiiakh. In: Panov, M. V. (Ed.) Russkij iazyk i sovetskoe obshchestvo. Fonetika sovremennogo russkogo literaturnogo iazyka. Narodnye govory. Nauka, Moscow, pp. 42-56.

Lightner, T., 1968. An analysis of akan'e and ikan'e in Modern Russian Using the Notion of Markedness. In: Gribble, C. E. (Ed.) Studies Presented to Professor Roman Jakobson by His Students. Slavica Publishers, Cambridge, MA, pp. 188-200.

Padgett, J., 2004. Russian Vowel Reduction and Dispersion Theory. In: Phonological Studies 7. Kaitakusha, Tokyo, pp. 81-96.

Padgett, J., Tabain, M., 2005. Adaptive dispersion theory and phonological vowel reduction in Russian. Phonetica 62, 14-54.

Panov, M.V. 2004. O vlijanii grammatičeskoj analogii na proiznositel'nye normy v sovremennom russkom literaturnom jazyke. In Trudy po obščemu jazykoznaniju $i$ russkomu jazyku. Moscow. 479-510.

Thelin, N. B., 1971. On Stress Assignment and Vowel Reduction in Contemporary Standard Russian. Striv Service AB, Uppsala.

Timberlake, Alan, 2004. A Reference Grammar of Russian. Cambridge University Press, Cambridge.

Trubetzkoy, N., 1934. Das morfologische System der russischen Sprache. Travaux du Cercle linguistique de Prague 5.2.

$\mathrm{Yu}, \mathrm{A} ., 2007$. Understanding near mergers: The case of morphological tone in Cantonese. Phonology 24, 187-214. 